Single preterminal axon の割合４4）終板の長径．5) 多重神経支配の険索。

結果および考察 神経・筋接合部の分布様式は，輪 状甲状筋では, 起始・付着部, 直部と斜部の境界部を 除き全長の中央 $2 / 3 に$ 多く分布していた。後輪状披裂筋 ではところどころに接合部の集簇を認めながらもほ 浊全長にわたりみられた。甲状披裂筋および側輪状披 裂筋では，全長にわたり広くびまん性に分散して観察 された，披裂筋では，中央部において，逆 $\mathrm{Y}$ 字型から 扇型に認められた。このような分布様式の違いは，支 配神経の分岐様式の反映によると考えられる.2) Terminal branch points は, 2.3〜2.9であり, 各笳肉の間 において大きな差は諗められなかった，3） Single preterminal axon の割合は, 平均 $84 \%$ あ゙あり，いわゆ る duplex ending は，5〜10\%であった４）運動終板 の長径は, 27〜30 $\mu \mathrm{m}$ であり, 内唉頭筋の間では大差は なかった５）1本の筋線維につき 1 個の神経・筋接合 部が存在するもの以外にも，複数個の接合部が存在す るものも少ないながら認められた。このような接合部
では，1 本の nerve axon が接合部の外で分岐し，隣接 する複数個の運動終板に入るもの (duplex ending)， より中枢側で分汥あるいは異なる複数個の axon が運 動終板に入っているものが認められた。その他，多重 神経支配を受けている筋線維に認められるといわれて いる連銷状に配列する運動終板に似た状態も見られ た。内喉頭筋の神経支配に関し，この上うな複数個の 神経・筋接合部が存在することは, mono-axonal innervation 以外にも, poly-axonal innervation $の も の も$ 存 在すると考えられる。しかし，免疫組織学的検討から は，外眼筋のような slow tonic な機能を有するとは, 考えにくいが，少なくとも，通常の骨格筋における twitch な機能とは, 異なる可能性があり, 喉頭のもつ 複雑な機能を営むうえで重要な役割を果たしていると 考えられた。質問 丘村 熙(愛媛大).Polyaxonal innervation の上率は披裂筋と他の内喉頭筋の間に差 があったか. 応答 Polyaxonal innervation の各 筋肉における比率は明らかでないため，比較できてい ない.

\title{
381．ネコ胸骨甲状筋における笳紡鍕内線維の酵素活性に関する 定量組織化学的研究
}

\section{久 育男・豊田健司 - 園田隆郎・紀平晋也 - 宇野敏行 - 村上 泰 (京府医大)}

我々は舌骨下筋における種々の酔素活性を検索する ことにより，これらの筋の収縮特性を明らかにしてき た。一方，舌骨下筋には多くの筋紡錘が存在すること がよく知られて扔り，これらの筋の生理学的意義を考 えるうえで興味深い.今回，我々は舌骨下筋の一つで ある胸骨甲状筋の筋紡鍾に扔ける錘内線維の酵素活性 を定量的に検討した。

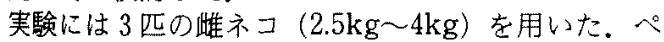
ントバルビタール麻酔下に胸骨甲状筋を摘出し, その 箭腹部を筇線維の走行と直角に約 $5 \mathrm{~mm}$ 幅で切断し た.この試料を直ちに, 液体窒素により冷した methylbutane にて凍結し, cryostatにて $10 \mu \mathrm{m}$ の連続切片を 作成した後，染色に呈した。今回用いた染色は下記の ごとくである.ATPase (pH4.3，4.6，9.0で各々前処 置したもの), phosphorylase, $\alpha$-GPD, PAS, SDH, $\mathrm{NADH}$

総計 5 個の筋紡錘について旁赤道部で検討した。上 述の 8 種の染色された連続切片上で, 筋紡錘周囲の鍾 外線維加 Type I, II A, II B, II C 各々 5 個を無 作為に選びこれらの線維と錘内線維ごとに透過率を microdensitometer にて測定した。次にこの透過率を 吸収率に変換した。すなわち，濃染する線維ほど高值 となる，すべての筋紡錘において 2 本の核礋線維と 4 $\sim 6$ 本の核鎖線維が認められ，四肢筋に存在する典型 的な筋紡錘であると考えられた.ATPase 染色では， 核軎線維は 2 種に鑑別可能であった。また，鍾内線維
の染色性は錘外線維のそれとは明らかに異なってい た。糖代謝の面からみると, phosphorylase 染色で核鎖 線維の一部が濃染するのが観察され, PAS染色におい ては核鎖線維は鍾外線維のいずれよりも明らかに濃染 することが碓認された。酸化環元醉素では，核筫線維 が濃染する傾向にあり，特に核裂線維 I は濃染した。 $\mathrm{NADH}$ 染色に扔いてすべての錘内線維は明らかに錘 外線維より濃染した結果は非常に興味深かつた。一方， $\mathrm{SDH}$ 染色では NADH 染色でみら机たような明らか な差はなかった。

以上より，錘内線維は錘外線維とは明らかに異なつ た組織化学所見を有すると考えられた。また，錘内線 維間に扔いても，各々異なった組織化学所見を有し， 核賴線維は 2 種に分類可能であった。質問 布村 進作 (徳島大)、酵素活性の差異は形態上何を反映して いるの䫆似する筋肉はあるか. 応答 筋線維 の性質はその支配されている紐胞の性質によって異な ると考光られ，この点から錘内線維が錘外線維と生化 学的性䐝が異なって当然といえる。この意義について は，現在のところ不明である。質問 丘村 熙(爱 媛大).11)錘内筋線維の夕イプ分類には錘外筋線維の 分類とはちがった $\mathrm{pH}$ の調整が必要なのか．2）核整線 維，核鎖線維それぞれにタイプ分類ができるのか. 応答 1） $\mathrm{pH}$ を変えなくとも，鑑別可能である，2）核 整線維は 2 種に分類出来るが，核鎖線維に招いては分 類不能であると考えられる。 